\title{
Zadania publiczne a zakres działania jednostek samorządu terytorialnego
}

1. Jak wynika z przyjętego tematu, przedmiotem niniejszego artykułu jest wskazanie zadań publicznych realizowanych na szczeblu samorządowym. Temat wydaje się interesujący i wart analizy ze względu na fakt, że pojęcie zadań publicznych jest bardzo często wykorzystywane zarówno na gruncie obowiązujących przepisów prawa, jak i praktyki ${ }^{1}$, bez jednoznacznego określenia jego ustawowego znaczenia. Posługiwanie się tym pojęciem także w stosunku do jednostek samorządu terytorialnego uzasadnia podjęcie przez autora próby zdefiniowania tego rodzaju zadań wykonywanych na szczeblu samorządowym.

Z uwagi na to, że obok pojęcia zadań publicznych ustawodawca posługuje się także określeniem zakresu działania jednostek samorządowych, często stosując je zamiennie, rozważania przeprowadzone w niniejszym artykule mają służyć odpowiedzi na pytanie, czy takie działanie legislatora jest uprawnione czy też niczym nieuzasadnione i merytorycznie wątpliwe.

W celu zilustrowania wybranego tematu analizie zostaną poddane dwa wątki. Pierwszy jest związany z próbą definicji zadań o charakterze publicznym, badanych na szczeblu samorządowym. Drugi zaś ma służyć wyjaśnieniu istoty i racjonalności stosowania pojęcia zakresu działania jednostek samorządu terytorialnego.

* Dr Elżbieta Feret - Katedra Finansów i Prawa Finansowego, Wyższa Szkoła Prawa i Administracji w Przemyślu.

${ }^{1}$ Zob. m.in.: T. Dębowska-Romanowska, Prawo finansowe. Część konstytucyjna wraz z częścia ogólnq, Warszawa 2010, s. 18; T. Rabska, Pozycja samorządu terytorialnego w Konstytucji, „Samorząd Terytorialny” 1995, nr 5, s. 19; L. Rajca, Osobowość publicznoprawna samorządu terytorialnego, „Przegląd Sądowy” 2001, nr 7-8, s. 39; L. Rajca, Konstrukcja osobowości prawnej samorzadu terytorialnego, „Samorząd Terytorialny” 2004, s. 19; W. Łączkowski, Zasada pomocniczości a finansowanie zadań publicznych, [w:] A. Dębiński, M. Gałązka, R. G. Hałas, K. Wiak (red.), Hominum causa omne ius constitutum est, Lublin 2006, s. 337; P. Krawczyk, Jednostka samorzadu terytorialnego jako publiczna osoba prawna, [w:] J. Buciński, D. Strus, R. Stec (red.), Samorząd terytorialny w Polsce. Wybrane zagadnienia ustroju i działalności, Warszawa 2009, s. 56. 
2. Źródło pochodzenia pojęcia zadania publicznego należy wywodzić z regulacji zawartych w Konstytucji Rzeczypospolitej Polskiej². Kolejno bowiem w jej art. 15 ust. 2 ustrojodawca przewiduje, że „Zasadniczy podział terytorialny państwa uwzględniający więzi społeczne, gospodarcze lub kulturowe i zapewniający jednostkom terytorialnym zdolność wykonywania zadań publicznych określa ustawa”; w art. 16 ust. 2, że „Samorząd terytorialny uczestniczy w sprawowaniu władzy publicznej. Przysługującą mu w ramach ustaw istotną część zadań publicznych samorząd wykonuje w imieniu własnym i na własną odpowiedzialność”; w art. 163, że „Samorząd terytorialny wykonuje zadania publiczne nie zastrzeżone przez Konstytucję lub ustawy dla organów innych władz publicznych"; zaś w art. 166 ust. 1 i ust. 2, że „Zadania publiczne służące zaspokajaniu potrzeb wspólnoty samorządowej są wykonywane przez jednostkę samorządu terytorialnego jako zadania własne, a jeżeli wynika to z uzasadnionych potrzeb państwa, ustawa może zlecić jednostkom samorządu terytorialnego wykonywanie innych zadań publicznych".

Jak wynika z przedstawionych unormowań, Ustawa zasadnicza, posługując się pojęciem zadań publicznych, łączy go wprost z samorządem terytorialnym zaś to, że badane pojęcie ma również zastosowanie do innych niż samorządowe organy władzy publicznej, wynika z interpretacji powołanego wyżej przepisu art. 163 Konstytucji. Zgodnie z nim, za zasadę należy uznać, że organy władz publicznych, innych niż samorządowe, realizują zadania publiczne ustanowione przez Konstytucję lub ustawy.

Istotną z punktu widzenia badanej problematyki zadań publicznych realizowanych przez jednostki samorządu terytorialnego jest kwestia, że Konstytucja, posługując się pojęciem tego rodzaju zadań, zarówno w odniesieniu do organów jednostek samorządu terytorialnego, jak i innych organów władzy publicznej, przybliża je wyłącznie w stosunku do szczebla samorządowego. W świetle bowiem powołanej już regulacji, wynikającej z art. 166 ust. 1 i ust. 2 Konstytucji, przyjąć należy, że zadania publiczne zastrzeżone dla jednostek samorządowych to te, które służąc zaspokajaniu potrzeb wspólnoty samorządowej, przyjmują postać zadań własnych albo zadań zleconych, określonych przepisami ustaw.

2.1. Pomijając $\mathrm{w}$ tym momencie wspomniane regulacje ustawowe ${ }^{3}$, warto zwrócić uwagę na fakt, że określenie zadań publicznych, którym posługuje się Konstytucja, jest obce unormowaniom Europejskiej Karty Samorządu Lokalnego (dalej: Karty) ${ }^{4}$. Z analizy jej urzędowego thumaczenia wynika, że Karta,

2 Ustawa z dnia 2 kwietnia 1997 r., Dz. U. Nr 78, poz. 483 ze zm.

${ }_{3}^{3}$ Za art. 87 Konstytucji regulacje ustawowe są kolejnym źródłem prawa powszechnie obowiązującego w Polsce, a po nich ratyfikowane umowy międzynarodowe.

${ }^{4}$ Sporządzona w Strasburgu dnia 15 października 1985 r., Dz. U. 1994 r. Nr 124, poz. 607 ze sprost. 
określając cel działalności samorządu lokalnego, posługuje się terminem zakresu działania samorządu, a nie pojęciem zadań publicznych ${ }^{5}$. Termin taki, zamiennie z terminem kompetencji oraz spraw publicznych, pojawia się w kolejnych ustępach art. 4, gdzie m.in. zgodnie z treścią ust. 2 ,Społeczności lokalne mają - w zakresie określonym prawem - pełną swobodę działania w każdej sprawie, która nie jest wyłączona $\mathrm{z}$ ich kompetencji lub nie wchodzi w zakres kompetencji innych organów władzy”, a za ust. 3 „Generalnie odpowiedzialność za sprawy publiczne powinny ponosić przede wszystkim te organy władzy, które znajdują się najbliżej obywateli. Powierzając te funkcje innemu organowi władzy, należy uwzględnić zakres i charakter zadania oraz wymogi efektywności i gospodarności”.

Fakt, że Karta, definiując cel działalności samorządu lokalnego, nie posługuje się określeniem zadań publicznych, lecz innymi bliskoznacznymi, oznacza, że z punktu widzenia unormowań wynikających z Karty istotniejszym od sprecyzowania zadań publicznych jest wskazanie obszaru działalności samorządu lokalnego. Ten obszar, a nie zadania publiczne, na którym społeczności lokalne mają pełną swobodę działania w każdej sprawie, może być, mocą powołanych przepisów, ograniczony przez wyłączenie kompetencji organów lokalnych i przekazanie ich na rzecz innych organów władzy ${ }^{6}$.

W tym miejscu można zauważyć, że Konstytucja oraz Europejska Karta Samorządu Lokalnego w odmienny sposób podchodzi do określenia zasięgu działania jednostek samorządu terytorialnego. Wydaje się, że Ustawa zasadnicza, wprowadzając i posługując się określeniem zadań publicznych, zmierza do ich skonkretyzowania, podczas gdy Karta unika używania określenia zadań publicznych na rzecz ogólnego sformułowania zakresu działania samorządu lokalnego. Zabieg ten należy uznać za uzasadniony ze względu na uniwersalny charakter przepisów zawartych w Karcie, mających zastosowanie we wszystkich państwach respektujących jej postanowienia. W tym przypadku trudnym, a wręcz niemożliwym byłoby wskazanie dokładnego katalogu zadań publicznych realizowanych przez samorządy lokalne. Inaczej w przypadku Konstytucji, która regulując ustrój jednego państwa, wprowadza i posługuje się pojęciem zadań publicznych.

2.2. Wracając do unormowań konstytucyjnych, za zadania publiczne jak wskazano wyżej, należy uznać dwie kategorie: zadania własne jednostek samorządu terytorialnego i zadania zlecone jednostkom samorządowym. Za Ustawą zasadniczą, konkretyzacja tak określonych zadań publicznych powinna nastąpić $\mathrm{W}$ przepisach prawa materialnego ${ }^{7}$. W tym celu w pierwszej kolejności należy

\footnotetext{
${ }^{5}$ Tytuł art. 4 Europejskiej Karty Samorządu Lokalnego.

${ }^{6}$ Wynika z treści art. 4 ust. 4 Europejskiej Karty Samorządu Lokalnego.

7 Zgodnie z art. 87 Konstytucji.
} 
wykorzystać przepisy wynikające z ustaw samorządowych (nazywanych także ustawami ustrojowymi $)^{8}$, które powinny konkretyzować poszczególne rodzaje zadań publicznych realizowanych przez jednostki samorządu terytorialnego.

Dokonując interpretacji ustaw samorządowych odnośnie do analizowanej kwestii, można wskazać, że ustawodawca, określając rodzaje zadań publicznych na szczeblu samorządowym, wykazał niekonsekwencję. Z jednej strony bowiem, definiując zasięg działania jednostek samorządu terytorialnego, posłużył się pojęciem wprowadzonym konstytucyjnie. Odpowiednio bowiem w art. 2 ust. 1 ustawy o samorządzie gminnym i ustawy o samorządzie powiatowym, ustawodawca przewiduje, że odpowiednio gmina i powiat wykonują zadania publiczne w imieniu własnym i na własną odpowiedzialność. Tak jak, zgodnie z brzmieniem art. 2 ust. 2 ustawy o samorządzie województwa: „Do zakresu działania samorządu województwa należy wykonywanie zadań publicznych o charakterze wojewódzkim, nie zastrzeżonych ustawami na rzecz organów administracji rządowej”.

Z drugiej strony natomiast, ustawy te, konkretyzując zasięg działania jednostek samorządowych w miejsce stosowania za Konstytucją pojęcia zadań publicznych, modyfikują je albo zastępują nowymi. Już z tytułów Rozdziału 2 ustawy o samorządzie gminnym oraz Rozdziału 2 ustawy o samorządzie powiatowym wynika, że zawarte w nim regulacje dotyczą zakresu działania i zadań (nienazwanych publicznymi) odpowiednio gminy oraz powiatu. Podobnie w przypadku województw, Rozdział 2 został poświęcony wyłącznie określeniu zakresu działalności samorządu województwa, a nie wskazaniu jego zadań publicznych.

Nie tylko z przytoczonej nazwy rozdziałów, ale także z ich treści wynika, że każda $z$ trzech ustaw ustrojowych inaczej definiuje zasięg działania poszczególnych jednostek samorządu terytorialnego. Najwyraźniej wynika to z regulacji przyjętych dla określenia zakresu działania i zadań gminy.

W przypadku podstawowej jednostki samorządu terytorialnego, art. 6 ust. 1 ustawy o samorządzie gminnym przesądza o tym, że do zakresu działania gminy należą wszystkie sprawy publiczne (a nie zadania publiczne) o znaczeniu lokalnym niezastrzeżone ustawami na rzecz innych podmiotów. O zadaniach i sprawach (nieokreślonych jako publiczne) wspomina także art. 7. Zgodnie z jego treścią „Zaspokajanie zbiorowych potrzeb wspólnoty należy do zadań własnych gminy. W szczególności zadania własne obejmują sprawy [...]”.

Z przytoczonych unormowań bezsprzecznie wynika, że ustawodawca obok zastosowania pojęcia zakresu działania gminy posłużył się dodatkowym - sprawy publicznej, a nie zadania publicznego. Wykorzystanie przez przepisy ustawy o samorządzie gminnym pojęcia sprawy publicznej, oprócz tego że wynika ono

${ }^{8}$ Ustawa z dnia 8 marca 1990 r. o samorządzie gminnym (t.j. Dz. U. z 2001 r. Nr 142, poz. 1591 ze zm.), ustawa z dnia 5 czerwca 1998 r. o samorządzie powiatowym (t.j. Dz. U. z 2001 r. Nr 142, poz. 1592 ze zm.), ustawa z dnia 5 czerwca 1998 r. o samorządzie województwa (t.j. Dz. U. z 2001 r. Nr 142, poz. 1590 ze zm.). 
z cytowanych wyżej regulacji Europejskiej Karty Samorządu Lokalnego', warte jest krótkiego uzasadnienia doktrynalnego.

Pojęcie spraw publicznych pochodzi z połowy XIX w., kiedy to tworzył się samorząd terytorialny, a pojęcie spraw publicznych było stosowane znacznie częściej niż pojęcie zadań publicznych ${ }^{10}$. Poprzednio, jak też obecnie, sprawy publiczne to rodzaje spraw ważnych z punktu widzenia obywatela, a realizowane przez organy gminy ${ }^{11}$. Za sprawy publiczne należy zatem uznać te, które nie mają charakteru spraw prywatnych dotyczących życia osobistego, rodzinnego, religijnego wraz z dobrami osobistymi ${ }^{12}$. Tak rozumiane sprawy publiczne są traktowane w orzecznictwie sądowym jako synonim pojęcia zadań publicznych, bowiem określenie „do zakresu działania gmin należą sprawy publiczne [...]" należy utożsamiać z pojęciem zadań publicznych, czyli takich, które dotyczą interesu powszechnego, korzyści społecznej (utilitas publica), czyli korzyści znacznej części mieszkańców gminy ${ }^{13}$.

W świetle obowiązujących przepisów ustawy o samorządzie gminnym nie istnieje definicja spraw publicznych rozumianych jako zadania publiczne. Brak definicji pojęcia spraw publicznych podstawowej jednostki samorządu terytorialnego należy uzasadniać regulacją konstytucyjną, która wobec gminy stosuje zasadę subsydiarności. Zgodnie z art. 164 ust. 3 Ustawy zasadniczej, „Gmina wykonuje wszystkie zadania samorządu terytorialnego nie zastrzeżone dla innych jednostek samorządu terytorialnego". Przyjęte domniemanie właściwości realizacji zadań publicznych przez gminę nie pozostawia wątpliwości co do tego, że o ile przepis konkretnej ustawy nie zastrzega określonego zadania (publicznego) do właściwości organu innego niż gmina, sprawa taka pozostaje w gestii gminy.

Obok tej kardynalnej zasady przypisującej konieczność załatwiania wszystkich zadań - spraw (publicznych) przez gminę, nie należy zapominać także o regulacji wynikającej z powołanego wyżej art. 7 ust. 1 ustawy o samorządzie gminnym, która przewiduje także konieczność wykonywania przez gminę zadań własnych mających na celu zaspokajanie zbiorowych potrzeb wspólnoty. Rodzaje tych zadań, będących jednym z rodzajów konstytucyjnie nazwanych zadań publicznych, ustawodawca wylicza przykładowo, wskazując, że w szczególności obejmują one sprawy m.in.: ładu przestrzennego, gospodarki nieruchomościami, pomocy społecznej, ochrony zdrowia, transportu zbiorowego i dróg publicznych, kultury, ochrony zabytków i opieki nad zabytkami.

${ }^{9} \mathrm{Za}$ art. 4 ust. 3 Europejskiej Karty Samorządu Lokalnego.

${ }_{10}$ M. Miemiec, Ustrój samorzadu terytorialnego, [w:] Prawo administracyjne, Wrocław 2000, s. 184.

11 www.swiatowa.republika.pl, Zagadnienia ogólne dotyczace samorzadu terytorialnego.

12 Komentarz do bloga Tadeusza Lemańczyka na temat: „Sprawa publiczna” $i$, informacja publiczna", http://fedcba.ning.com/group/bi.

${ }_{13}$ Wyrok Trybunału Konstytucyjnego z dnia 21 października 2008 r., sygn. akt P 2/08 oraz A. Agopszowicz, Z. Gilowska, Ustawa o gminnym samorzadzie terytorialnym. Komentarz, Warszawa 1999, s. 62; A. Szewc, [w:] A. Szewc, G. Jyż, Z. Pławecki, Samorząd gminny. Komentarz, Warszawa 2005, s. 73, 74. 
Wyliczenie przykładowych rodzajów zadań (spraw) załatwianych przez gminę oznacza, że ustawa o samorządzie gminnym nie tworzy katalogu zamkniętego zadań własnych realizowanych przez gminę, odsyłając do przepisów odrębnych ustaw, które jak wynika $\mathrm{z}$ art. 7 ust. 2 ustawy określają, które $\mathrm{z}$ nich mają charakter obowiązkowy. To, że należy im przypisać status zadań publicznych wynika z treści uchwały podjętej przez Trybunał Konstytucyjny w dniu 27 września 1994 r., która wskazała że „zadania samorządu terytorialnego mają charakter zadań publicznych w tym znaczeniu, że służą zaspokojeniu potrzeb zbiorowych społeczności czy to lokalnych, w wypadku zadań własnych, czy zorganizowanego w państwo całego społeczeństwa, jak w wypadku zadań zleconych"14.

3. Ustawa o samorządzie powiatowym, określając, jak wskazano wyżej, zakres działania i zadania powiatu, konsekwentnie za Konstytucją, w art. 4 ust. 1 przyjmuje, że powiat realizuje wprawdzie zadania publiczne, ale o charakterze ponadgminnym. Rozbudowanie przez ustawodawcę pojęcia zadań publicznych o wskazanie ich charakteru ponadgminnego należy uznać za zabieg słuszny i potrzebny, służący potwierdzeniu roli tej jednostki samorządowej. Powiat, będąc lokalną jednostką samorządu terytorialnego, pośrednią między gminą a województwem samorządowym, pełni funkcje uzupełniające i wyrównawcze wobec gminy. Wraz z gminą zapewnia realizację całokształtu zadań publicznych o charakterze lokalnym w strukturach samorządowych ${ }^{15}$. W szczególności powiat stał się właściwy w sprawach należących wcześniej do kierowników rejonowych urzędów administracji rządowej oraz organów rządowej administracji specjalnej, a także przejął część spraw przysługujących przed reformą wojewodzie, np. w zakresie ochrony zdrowia i oświaty ponadpodstawowej, o czym szerzej w dalszej części artykułu.

Analogicznie do przytoczonych regulacji wywodzących się z ustawy o samorządzie powiatowym, modyfikacja pojęcia zadań publicznych została również zastosowana w ustawie o samorządzie województwa. Wystarczy przypomnieć brzmienie jej art. 2 ust. 2, wskazujące na to że „Do zakresu działania samorządu województwa należy wykonywanie zadań publicznych o charakterze wojewódzkim, nie zastrzeżonych ustawami na rzecz organów administracji rządowej”. Potraktowanie przez ustawodawcę samorządu województwa w sposób odmienny niż gmina można tłumaczyć tym, że podobnie jak powiat - zgodnie z art. 164 ust. 2 Konstytucji, należy do innych niż gmina jednostek samorządu terytorialnego ${ }^{16}$.

${ }^{14}$ Sygn. akt W. 10/93, OTK 1994, cz. II, poz. 46. Podobnie „Zarówno zlecone, jak i własne zadania samorządu terytorialnego są zadaniami publicznymi w rozumieniu obowiązującego prawa", orzeczenie Trybunału Konstytucyjnego z dnia 20 listopada 1996 r., sygn. akt K 27/95.

${ }_{15}$ Z. Niewiadomski, Ustrój samorządu terytorialnego i administracji rządowej po reformie, Warszawa 1998, s. 29.

${ }^{16}$ Zgodnie z brzmieniem art. 164 ust. 1 Konstytucji: „Podstawową jednostką samorządu terytorialnego jest gmina. 2. Inne jednostki samorządu regionalnego albo lokalnego i regionalnego określa ustawa". 
Ten szczególny charakter województwa należy wiązać z obszarem regionalnym, a nie lokalnym jego działania. Jego regionalne usytuowanie sprawia, że jest jednostką samorządową właściwą do określania m.in. strategii rozwoju województwa, uwzględniającą w szczególności następujące cele:

- pielęgnowanie polskości oraz rozwój i kształtowanie świadomości narodowej, obywatelskiej i kulturowej mieszkańców, a także pielęgnowanie i rozwijanie tożsamości lokalnej;

- pobudzanie aktywności gospodarczej;

- podnoszenie poziomu konkurencyjności i innowacyjności gospodarki województwa;

- zachowanie wartości środowiska kulturowego i przyrodniczego przy uwzględnieniu potrzeb przyszłych pokoleń;

- kształtowanie i utrzymanie ładu przestrzennego ${ }^{17}$.

Na gruncie przepisów powołanej ustawy należy przyjąć, że wskazane cele województwo realizuje w ramach zadań publicznych o charakterze wojewódzkim.

Posługując się pojęciem zadań publicznych zarówno w przypadku powiatu, jak i samorządu województwa ustawodawca tworzy ich przykładowy katalog, wskazując, że w przypadku powiatu zadania własne dotyczą m.in.: edukacji publicznej, promocji i ochrony zdrowia, pomocy społecznej, wspierania rodziny i systemu pieczy zastępczej, polityki prorodzinnej, wspierania osób niepełnosprawnych, transportu zbiorowego i dróg publicznych, kultury oraz ochrony zabytków i opieki nad zabytkami ${ }^{18}$. Ponadto, na mocy art. 4 ust. 2-3 ustawy o samorządzie powiatowym, do zadań (publicznych) powiatu należy również zapewnienie wykonywania określonych w ustawach zadań i kompetencji kierowników powiatowych służb, inspekcji i straży, a ustawy mogą określać inne zadania powiatu.

W przypadku samorządu województwa niemożliwe jest także pełne zdefiniowanie pojęcia zadań publicznych o charakterze wojewódzkim, bowiem analogicznie jak w powiecie ich wyliczenie ma charakter jedynie przykładowy. Jak wynika z regulacji ustawy, do zadań własnych, należących do właściwości samorządu województwa, należą w szczególności zadania z zakresu: edukacji publicznej, w tym szkolnictwa wyższego, promocji i ochrony zdrowia, kultury oraz ochrony zabytków i opieki nad zabytkami, pomocy społecznej, wspierania rodziny i systemu pieczy zastępczej, polityki prorodzinnej ${ }^{19}$.

4. Omawiając pojęcie zadań publicznych, nie sposób pominąć jeszcze jednego określenia bliskoznacznego, którym posługują się ustawy samorządowe dla wskazania konstytucyjnie nazwanych zadań publicznych, realizowanych

\footnotetext{
17 Za art. 11 ust. 1 ustawy o samorządzie województwa.

$18 \mathrm{Za}$ art. 14 ust. 1 pkt 1-7 ustawy o samorządzie powiatowym.

19 Za art. 14 ust. 1 pkt 1-5 ustawy o samorządzie województwa.
} 
przez jednostki samorządowe. Zadania o charakterze użyteczności publicznej ${ }^{20}$, bo o nich mowa, to - zgodnie $\mathrm{z}$ art. 9 ust. 3 ustawy o samorządzie gminnym - takie zadania własne gminy, których celem jest bieżące i nieprzerwane zaspokajanie zbiorowych potrzeb ludności $\mathrm{w}$ drodze świadczenia usług powszechnie dostępnych $^{21}$. O tego typu zadaniach wspomina także art. 6 ust. 2 ustawy o samorządzie powiatowym, w którym ustawodawca wyłącza możliwość prowadzenia przez powiat działalności gospodarczej wykraczającej właśnie poza zadania o charakterze użyteczności publicznej oraz art. 13 ustawy o samorządzie województwa, na podstawie którego województwo może w sferze użyteczności publicznej tworzyć spółki z ograniczoną odpowiedzialnością, spółki akcyjne lub spółdzielnie, a także przystępować do takich spółek lub spółdzielni.

Doprecyzowania pojęcia zadań o charakterze użyteczności publicznej dokonują przepisy ustawy o gospodarce komunalnej ${ }^{22}$, która zgodnie z art. 1 określa „Zasady i formy gospodarki komunalnej jednostek samorządu terytorialnego, polegające na wykonywaniu przez te jednostki zadań własnych, w celu zaspokojenia zbiorowych potrzeb wspólnoty samorządowej”. Ten przyjęty przez ustawodawcę cel ma być osiągnięty poprzez wykonywanie „zadań o charakterze użyteczności publicznej, $[\ldots]$ w drodze świadczenia usług powszechnie dostępnych". Za zadanie użyteczności publicznej, w myśl tej regulacji, należy uznać zatem wykonywanie przez jednostki samorządu terytorialnego ich zadań własnych w celu bieżącego i nieprzerwanego zaspokajania zbiorowych potrzeb ludności w drodze świadczenia usług powszechnie dostępnych ${ }^{23}$.

5. W celu przybliżenia zadań publicznych realizowanych przez jednostki samorządowe na podstawie przepisów ustaw samorządowych nie należy zapominać także o drugim rodzaju zadań, wskazanych przez Konstytucję, przyjmujących postać zadań zlecanych do wykonania jednostkom samorządu terytorialnego. Są to takie zadania, których wykonywanie leży w interesie nie tyle samych tylko mieszkańców jednostki samorządu terytorialnego, ile raczej w interesie

${ }^{20} \mathrm{O}$ tego rodzaju zadaniach pisze również m.in.: T. Dobek, Nowe formy zlecania i finansowania zadań publicznych jako wyzwanie dla regionalnych izb obrachunkowych $w$ Polsce, „Finanse Komunalne" 2007, nr 12.

${ }^{21}$ To, że gmina może realizować zadania poza sferą użyteczności publicznej, wynika wprost $\mathrm{z}$ art. 6 ust. 2 i ust. 3 ustawy o samorządzie gminnym, zgodnie z którym „Gmina oraz inna gminna osoba prawna może prowadzić działalność gospodarczą wykraczającą poza zadania o charakterze użyteczności publicznej wyłącznie w przypadkach określonych w odrębnej ustawie. Formy prowadzenia gospodarki gminnej, w tym wykonywania przez gminę zadań o charakterze użyteczności publicznej, określa odrębna ustawa".

${ }^{22}$ Ustawa z dnia 20 grudnia 1996 r., t.j. Dz. U. z 2011 r. Nr 45, poz. 236.

${ }^{23}$ Szerzej na ten temat zob. A. Mituś, Gospodarka komunalna gminy [w:] Gospodarka komunalna gminy. Kontrowersje wokót ustawy, „Przegląd Samorządowy. Monitor Zamówień Publicznych" 2005 , nr 5, s. 35-37. 
ogólnopaństwowym lub takie, które leżą w kompetencji innego podmiotu, lecz ich wykonywanie ze względów pragmatycznych zostało powierzone szczeblowi samorządowemu ${ }^{24}$.

Cechą powierzenia zadania do realizacji jednostce samorządowej jest to, że w ślad za powierzeniem takiego zadania publicznego muszą podążać odpowiednie środki finansowe ${ }^{25}$. W praktyce oznacza to tyle, że powierzenie jednostkom samorządowym wykonywania jakichś dodatkowych zadań jest konstytucyjnie dopuszczalne pod warunkiem przyznania im na ten cel dodatkowych pieniędzy, co wynika wprost z treści art. 167 ust. 4 Konstytucji: „Zmiany w zakresie zadań i kompetencji jednostek samorządu terytorialnego następują wraz z odpowiednimi zmianami w podziale dochodów publicznych".

W świetle ustaw samorządowych zadania publiczne o charakterze zleconych można podzielić na te zlecone ustawami i przez organy administracji rządowej oraz wykonywane na podstawie porozumienia zawartego z organami administracji rządowej. Przepisy odrębnych ustaw mogą nakładać na jednostki samorządu terytorialnego obowiązek wykonywania zadań zleconych z zakresu administracji rządowej, a także z zakresu organizacji przygotowań i przeprowadzenia wyborów powszechnych oraz referendów ${ }^{26} . Z$ treści art. 49 ustawy o dochodach jednostek samorządu terytorialnego wynika, że jednostka samorządu terytorialnego wykonuje zadania zlecone z zakresu administracji rządowej oraz inne zadania zlecone także przez organ administracji rządowej.

Z kolei zadania wykonywane na podstawie porozumienia sa realizowane przez gminę, która może wykonywać zadania z zakresu właściwości powiatu oraz zadania z zakresu właściwości województwa na podstawie porozumień z tymi jednostkami samorządu terytorialnego ${ }^{27}$. Także powiat może zawierać z organami administracji rządowej porozumienia w sprawie wykonywania zadań publicznych z zakresu administracji rządowej. Powiat może zawierać porozumienia w sprawie powierzenia prowadzenia zadań publicznych z jednostkami lokalnego samorządu terytorialnego, a także z województwem, na którego obszarze znajduje się terytorium powiatu ${ }^{28}$. Z kolei województwo może zawierać z innymi województwami oraz jednostkami lokalnego samorządu terytorialnego z obszaru województwa porozumienia w sprawie powierzenia prowadzenia zadań publicznych ${ }^{29}$.

${ }^{24}$ Zadania zlecone jednostek samorzadu terytorialnego, [w:] M. Chmaj (red.), Leksykon samorzadu terytorialnego, Warszawa 1999.

${ }^{25}$ Wynika bezpośrednio z wyżej cytowanej treści art. 166 ust. 2 Konstytucji RP oraz przepisów art. 45-46 oraz 48-49 ustawy z dnia 13 listopada 2003 r. o dochodach jednostek samorządu terytorialnego, t.j. Dz. U. z 2010 r. Nr 80, poz. 526 ze zm.

${ }^{26}$ Odpowiednio za art. 8 ust. 1 ustawy o samorządzie gminnym, art. 4a ustawy o samorządzie powiatowym, art. 14 ust. 3 ustawy o samorządzie województwa.

${ }^{27} \mathrm{Za}$ art. 8 ust. 2 i ust. 2 a ustawy o samorządzie gminnym.

${ }^{28} \mathrm{Za}$ art. 5 ust. 1 i ust. 2 ustawy o samorządzie powiatowym.

${ }^{29} \mathrm{Za}$ art. 8 ust. 2 ustawy o samorządzie województwa. 
Z przedstawionych unormowań dotyczących zadań publicznych - zleconych wynika, że ustawodawca posługuje się pojęciem zadań (czasami określonych nawet publicznymi) choć zmodyfikowanym o wskazanie ich zakresu. Wydaje się, że takie stosowanie pojęcia zadań publicznych ma na celu, podobnie jak to miało miejsce w przypadku zadań własnych, ogólne zarysowanie zadań publicznych, doprecyzowywanych mocą przepisów odrębnych ustaw i przez organy administracji rządowej oraz treścią porozumień zawieranych przez jednostki samorządowe $\mathrm{z}$ organami administracji rządowej.

6. Przeprowadzone rozważania skłaniają do uznania, że wbrew powszechnemu zastosowaniu pojęcia zadań publicznych również na szczeblu samorządowym trudne jest jego jednoznaczne doprecyzowanie, bowiem obowiązujące przepisy prawa swobodnie posługują się tym pojęciem, dowolnie go modyfikując. Ponadto, jak dowodzą powołane regulacje Europejskiej Karty Samorządu Lokalnego oraz ustaw samorządowych, miejsce pojęcia zadań publicznych zastępuje określenie szersze, wskazujące na zakres działania jednostek samorządowych.

Określenie zakresu działania, rozumianego jako wskazanie obszaru działalności jednostek samorządu terytorialnego, a nie zamkniętego katalogu zadań publicznych, należy wiązać z przysługującą jednostkom samorządu terytorialnego samodzielnością ${ }^{30}, \mathrm{w}$ tym również finansową ${ }^{31}$, podlegającą ochronie sądowej32. Ich samodzielność wynika wprost z przepisów Europejskiej Karty Samorządu Lokalnego, która w ramach Rozdziału 9 dotyczącego zasad finansowych społeczności lokalnych ${ }^{33}$ uznaje za podstawową tę, że „Społeczności lokalne mają prawo, w ramach narodowej polityki gospodarczej, do posiadania własnych wystarczających zasobów finansowych, którymi mogą swobodnie dysponować w ramach wykonywania swych uprawnień".

Wskazana przepisami Karty samodzielność finansowa samorządu lokalnego została zagwarantowana także przepisami Konstytucji. Analogicznie jak w innych powołanych wyżej regulacjach związanych z samorządem terytorialnym, Ustawa zasadnicza, definiując samodzielność finansową jednostek samorządu terytorialnego, posługuje się określeniem zadań. Z art. 167 ust. 1 wynika bowiem, że ,Jednostkom samorządu terytorialnego zapewnia się udział w dochodach publicznych odpowiednio do przypadających im zadan". To, że te zadania należy traktować jako publiczne, należy wywodzić z treści art. 163 Konstytucji, która

${ }^{30} \mathrm{~W}$ literaturze przedmiotu wyróżnia się także samodzielność administracyjną, samodzielność ustrojową oraz majątkową samorządu terytorialnego. Zob. szerzej na ten temat: J. Jagoda, Sąowa ochrona samodzielności jednostek samorzadu terytorialnego, Warszawa 2011, s. 68-81.

${ }^{31} \mathrm{Na}$ ten temat por. szerzej: M. Mączyński, Samodzielność a samorządnośćc, [w:] M. Stec, M. Mączyński, Nadzór nad samorządem a granice jego samodzielności, Warszawa 2011, s. 23 i n. oraz J. Jagoda, op. cit., s. 78-81.

${ }^{32} \mathrm{Na}$ mocy art. 165 Konstytucji oraz odpowiednio za art. 2 ust. 2 ustawy o samorządzie gminnym, art. 2 ust. 2 ustawy o samorządzie powiatowym, art. 6 ust. 2 ustawy o samorządzie województwa.

33 Tytuł art. 9 Karty. 
stanowi, że „Samorząd terytorialny wykonuje zadania publiczne [...]”. Powołane unormowania konstytucyjne ${ }^{34}$ stanowią gwarancję zabezpieczenia środków finansowych potrzebnych jednostkom samorządowym na realizację stojących przed nimi zadań publicznych, o zakresie określonym przez ustawy ustrojowe oraz inne przepisy prawa materialnego ${ }^{35}$.

7. Niestety, porządek wprowadzony przez Konstytucję w Rozdziale VII, dotyczącym samorządu terytorialnego odnośnie stosowania pojęcia zadań publicznych, został naruszony przez przepisy wynikające z jej Rozdziału X poświęconego finansom publicznym. Jak wynika bowiem z art. 216 ust. 1 Konstytucji, środki finansowe są gromadzone i wydatkowane w sposób określony w ustawie na cele publiczne ${ }^{36}$, a nie zadania publiczne.

Ustawa o finansach publicznych, która ma precyzować zasady gromadzenia i wydatkowania środków finansowych, nie wyjaśnia znaczenia pojęcia celu publicznego, zastosowanego przez Konstytucję. Skutkiem tego jest stosowanie przez ustawodawcę zamiennie zarówno pojęcia zadań publicznych, jak i celów publicznych. Na gruncie regulacji związanych ze szczeblem samorządowym o celach publicznych wspomina w art. 221 ust. 1 ustawy o finansach publicznych W związku z możliwością udzielania przez jednostki samorządu terytorialnego dotacji celowych dla podmiotów niezaliczanych do sektora finansów publicznych. Pojęcie zadań publicznych pojawia się natomiast częściej, bo w katalogu jednostek tworzących sektor finansów publicznych realizujących zadania publiczne ${ }^{37}$, w definicji dotacji służącej finansowaniu lub dofinansowaniu realizacji zadań publicznych $^{38}$, w określeniu zasad udzielania pożyczki z budżetu państwa jednostkom samorządu terytorialnego, realizującym program postępowania ostrożnościowego, jeżeli występuje zagrożenie wykonania zadań publicznych ${ }^{39}$.

${ }^{34}$ Traktowane jako zasada adekwatności. Zob. szerzej na ten temat: T. Dębowska-Romanowska, op. cit., s. 230.

${ }^{35}$ Ułatwienie realizacji tych zadań stanowią, za art. 167 ust. 2 Konstytucji RP, także konstytucyjnie przypisane rodzaje obligatoryjnych dochodów jednostek samorządu terytorialnego w postaci ich dochodów własnych, subwencji ogólnych i dotacji celowych. Uszczegółowienie poszczególnych rodzajów dochodów następuje na gruncie przepisów ww. ustawy o dochodach jednostek samorządu terytorialnego oraz prawo, wprowadzone na podstawie art. 9 ust. 3 Europejskiej Karty Samorządu Lokalnego, pozwalające jednostkom samorządowym ustalać wysokość podatków i opłat lokalnych w zakresie określonym w ustawie - zgodnie z brzmieniem art. 168 Konstytucji RP.

${ }^{36}$ Ten cel publiczny, w ujęciu konstytucyjnym, znajduje swoje normatywne odzwierciedlenie także w treści art. 21 ust. 2 Konstytucji RP, według którego „Wywłaszczenie jest dopuszczalne jedynie wówczas, gdy jest dokonywane na cele publiczne i za słusznym odszkodowaniem". Zob. np. P. Krawczyk, op. cit., s. 52. O celach, a nie zadaniach publicznych, pisze także S. Fundowicz, Wspótczesne problemy prawa publicznego, Lublin 1999, s. 47.

${ }^{37}$ Art. 9 pkt 14 ustawy o finansach publicznych.

${ }^{38}$ Art. 126 ustawy o finansach publicznych.

${ }^{39}$ Art. 224 ust. 1 pkt 5 ustawy o finansach publicznych. 
Wykorzystanie przez ustawodawcę w art. 221 ust. 1 ustawy pojęcia celów publicznych, a nie zadań publicznych skłania do przyjęcia, że było to jego rozmyślne działanie, a nie przypadek. Chcąc odpowiedzieć na pytanie, dlaczego doszło do zamiany pojęcia zadań publicznych na pojęcie celów publicznych, należy sięgnąć do treści powołanego art. 221 ustawy. Zgodnie z nim podmioty niezaliczane do sektora finansów publicznych i niedziałające w celu osiągnięcia zysku mogą otrzymywać z budżetu jednostki samorządu terytorialnego dotacje celowe na cele publiczne związane $\mathrm{z}$ realizacją zadań tej jednostki. „Zlecenie zadania i udzielenie dotacji następuje zgodnie z przepisami ustawy z dnia 24 kwietnia 2003 r. o działalności pożytku publicznego i o wolontariacie ${ }^{40}$, a jeżeli dotyczy ono innych zadań niż określone w tej ustawie - na podstawie umowy jednostki samorządu terytorialnego z podmiotem [...]".

W świetle powołanej regulacji istnieje możliwość zdefiniowania, choć niepełnego, co wynika z faktu, że umowa zawarta pomiędzy jednostką samorządową a podmiotem może określać inne zadania, pojęcia zadań publicznych realizowanych przez jednostki niezaliczane do sektora finansów publicznych. W rozumieniu bowiem przepisów ustawy działalnością pożytku publicznego jest działalność społecznie użyteczna, prowadzona przez organizacje pozarządowe w sferze zadań publicznych określonych $w$ ustawie ${ }^{41}$. Przepisy ustawy wprowadzają i definiują w art. 4 ust. 1 pojęcie zadań publicznych ${ }^{42}$ wskazując, że „Sfera zadań publicznych obejmuje zadania w zakresie: 1) pomocy społecznej, w tym pomocy rodzinom i osobom w trudnej sytuacji życiowej oraz wyrównywania szans tych rodzin i osób; 1a) zapewnienia zorganizowanej opieki byłym żołnierzom zawodowym, którzy uzyskali uprawnienie do emerytury wojskowej lub wojskowej renty inwalidzkiej, inwalidom wojennym i wojskowym oraz kombatantom; 2) działalności charytatywnej $[\ldots] "$.

40 T.j. Dz. U. z 2010 r. Nr 234, poz. 1536 ze zm.

${ }^{41} \mathrm{Za}$ art. 3 ust. 2 i 3 ustawy o pożytku publicznym i wolontariacie, organizacjami pozarządowymi, które mogą prowadzić tego rodzaju działalność, są niebędące jednostkami sektora finansów publicznych i niedziałające $\mathrm{w}$ celu osiągnięcia zysku osoby prawne lub jednostki nieposiadające osobowości prawnej utworzone na podstawie przepisów ustaw, w tym fundacje i stowarzyszenia. Ponadto, działalność pożytku publicznego może być prowadzona także przez: osoby prawne i jednostki organizacyjne działające na podstawie przepisów ustawy z dnia 17 maja 1989 r. o stosunku Państwa do Kościoła Katolickiego w Rzeczypospolitej Polskiej (Dz. U. Nr 29, poz. 154 ze zm.) oraz ustawy z dnia 17 maja 1989 r. o gwarancjach wolności sumienia i wyznania (t.j. Dz. U. z 2005 r. $\mathrm{Nr} 231$, poz. 1965 ze zm.), jeżeli ich cele statutowe obejmują prowadzenie działalności pożytku publicznego.

${ }^{42}$ Choć nie należy zapominać o tym, że za art. 4 ust. 2 ww. ustawy Rada Ministrów może określić, w drodze rozporządzenia, zadania w zakresie innym niż wymienione w ust. 1 jako należące do sfery zadań publicznych, kierując się ich szczególną społeczną użytecznością oraz możliwością ich wykonywania przez podmioty, o których mowa w art. 5 ust. 1, w sposób zapewniający wystarczające zaspokajanie potrzeb społecznych. 
Nierozstrzygniętą pozostaje natomiast kwestia wprowadzonego przez ustawę pojęcia celów publicznych. Ze względu na brak definicji ustawowej, na gruncie przedstawionych unormowań można przyjąć, że cel publiczny jest pojęciem nadrzędnym w stosunku do pojęcia zadań publicznych ${ }^{43}$. Budżet samorządowy może bowiem udzielać dotacji celowej podmiotom niezaliczanym do sektora finansów publicznych po to, by mogły one zrealizować cele publiczne. Te cele publiczne zostaną osiągnięte wówczas, gdy podmiot spoza sektora finansów publicznych wykona zadania publiczne określone przez ustawę o pożytku publicznym i wolontariacie. Pojęcie zadania, w tym publicznego, należy podporządkować pojęciu celu również publicznego jako kategorii kierunkowej, oznaczającej dążenie do osiągnięcia stanu rzeczy. Tak więc relacja znaczeniowa między tymi pojęciami sprowadza się do relacji „tego co ma być realizowane teraz” do „tego co ma być osiągnięte w przyszłości”. Inaczej mówiąc, zadaniem jest to, co mamy czynić w dążeniu do wyznaczonego celu ${ }^{44}$.

8. Reasumując przeprowadzone, na podstawie regulacji prawnych, literatury przedmiotu oraz orzecznictwa sądowego rozważania dotyczące zadań publicznych i zakresu działania jednostek samorządu terytorialnego można przyjąć następujące wnioski de lege lata.

Po pierwsze, obowiązujące przepisy prawa, określając obszar działania jednostek samorządu terytorialnego, posługują się zróżnicowanymi pojęciami. Obok klasycznego - zadań publicznych, które wprowadza Konstytucja, przepisy odrębnych ustaw posługują się także innymi.

Po drugie, pojęcie zadań publicznych należy uznać za szczególnie ważne z punktu widzenia działania jednostek samorządu terytorialnego, bowiem właśnie w stosunku do tych jednostek Ustawa zasadnicza dokonuje doprecyzowania ich znaczenia; dzieląc je na zadania własne i zlecone.

${ }^{43}$ Za przyjęciem tezy, że pojęcie celu publicznego jest nadrzędne wobec pojęcia zadań publicznych, zdają się przemawiać także przepisy wynikające z ustawy z dnia 21 sierpnia $1997 \mathrm{r}$. o gospodarce nieruchomościami (t.j. Dz. U. z 2010 r. Nr 102, poz. 651 ze zm.). Ustawa ta, konkretyzując cele publiczne, wskazuje, że są nimi m.in.: 1) wydzielanie gruntów pod drogi publiczne i drogi wodne, budowa, utrzymywanie oraz wykonywanie robót budowlanych tych dróg, obiektów i urządzeń transportu publicznego, a także łączności publicznej i sygnalizacji; 1a) wydzielenie gruntów pod linie kolejowe oraz ich budowa i utrzymanie; 1b) wydzielanie gruntów pod lotniska, urządzenia i obiekty do obsługi ruchu lotniczego, w tym rejonów podejść, oraz budowa i eksploatacja tych lotnisk i urządzeń; [...]; 10) inne cele publiczne określone w odrębnych ustawach, np. ustawie 28 września 1991 r. o lasach (t.j. Dz. U. z 2011 r. Nr 12, poz. 59 ze zm.). Na ten temat zob. również orzeczenie Samorządowego Kolegium Odwoławczego z dnia 21 grudnia 2000 r., SKO 4114/763/00.

${ }^{44}$ Z. Ziembiński, O pojmowaniu celu, zadania, roli i funkcji prawa, „Państwo i Prawo” 1987, z. 12, s. 18 oraz E. Sobol (red.), Wielki słownik języka polskiego, Warszawa 2006, s. 78, 216, 813. 
Po trzecie, Europejska Karta Samorządu Lokalnego, stanowiąca podstawę dla funkcjonowania jednostek samorządu terytorialnego także w Polsce, nie stosuje pojęcia zadań publicznych, koncentrując się na wskazaniu zakresu działania samorządu lokalnego.

Po czwarte, ustawy ustrojowe oraz inne przepisy prawa materialnego, które mają doprecyzowywać pojęcie zadań publicznych i zakresu działania jednostek samorządu terytorialnego, stosują terminologię zaczerpniętą zarówno z Konstytucji oraz Europejskiej Karty Samorządu Lokalnego, jak i tworzą nowe pojęcia.

Po piąte, odmienna od pojęcia zadań publicznych i zakresu działania jednostek samorządu terytorialnego terminologia pojawia się także w samej Konstytucji i ustawie o finansach publicznych dla określenia zasad finansowania działalności jednostek samorządowych.

Ze względu na wykazany chaos terminologiczny, w ramach wniosków de lege ferenda, należy postulować w pierwszej kolejności konieczność uporządkowania pojęć wykorzystywanych dla zdefiniowania zadań publicznych i zakresu działania jednostek na szczeblu samorządowym. W tym celu istotne jest ustalenie hierarchii znaczeniowej stosowanych określeń.

Niewątpliwie pojęcie zakresu działania jednostek samorządu terytorialnego należy traktować jako to najszersze, bo określające obszar działalności jednostek samorządowych odmienny od obszaru działalności jednostek państwowych. W ramach zakresu działania jednostek samorządowych zasadne jest ustalenie celów publicznych ich działalności, a dopiero później wskazanie jednolicie nazwanych zadań publicznych.

Należy uznać za niepotrzebne wprowadzanie przez przepisy prawa materialnego nowych określeń, które powodują jedynie bałagan terminologiczny. Skoro bowiem Konstytucja, wskazując obszar działania jednostek samorządowych, posługuje się pojęciem zadań publicznych, to także przepisy prawa materialnego powinny stosować to określenie. Zastępowanie go innymi, bez wprowadzania precyzyjnej definicji, powoduje niepotrzebne kontrowersje i wątpliwości natury kompetencyjnej.

Istotnym także jest uporządkowanie pojęć związanych z określeniem sposobu finansowania zadań publicznych realizowanych przez jednostki samorządowe. W tej kwestii należy postulować, by ustawa o finansach publicznych stosowała jednolite pojęcie - zadań, a nie celów publicznych.

Za radykalny, ale wydaje się, że najistotniejszy z punktu widzenia badanej problematyki, należy uznać postulat wprowadzenia jednoznacznej i wyczerpującej definicji zadań publicznych gmin, powiatów i samorządu województwa do odpowiednio ustawy o samorządzie gminnym, ustawy o samorządzie powiatowym i ustawy o samorządzie województwa. Takie skatalogowanie nazwanych zadań publicznych, bez konieczności sięgania do innych przepisów prawa materialnego, wpłynęłoby na przejrzystość rodzajów zadań obowiązkowo realizowanych na szczeblu samorządowym. 